\title{
Radu Toderici
}

\section{Romanion Cinema in the 1260s: Socialist Modernity vs. Cinematic Modernism}

\begin{abstract}
One of the most important traits of Romanian fiction films released during the 1960 s is their emphasis on leisure and moderate consumption, their enthusiasm for industrialization and urbanization, their reflection of a socialist society which gives its citizens the opportunity to have a decent standard of living - in brief, an emphasis on the many facets of socialist modernity. The 1960 s are, indeed, for socialist Romania a period characterized by prosperity and a relative openness towards Western influences. One such influence is that of Western modern cinema. This paper reflects upon the clash of values inherent in Romanian modern cinema of the 1960s; infused by anxieties prevalent in the other, Western modernization project, as they were reflected in Western cinema, Romanian modern films present an ambiguous and self-critical version of socialist modernity, which in some cases was harshly sanctioned by Romanian film officials and state apparatchiks.
\end{abstract}

Keywords: Socialist Modernity; Modernism; Cinematic Modernism; Western Influence; Socialist Realism.

\section{RADU TODERICI}

Babeș-Bolyai University, Cluj-Napoca, Romania radutoderici@yahoo.com

DOI: $10.24193 /$ cechinox.2019.37.25

\section{Before the Divide}

mong the hundred or so films re1960s, the lesser known Cerul n-are gratiil The Sky Has No Bars (1963) probably encapsulates in the most concise and straightforward manner the basic assumptions about socialist art typical for that era. Written and directed by Romanian filmmaker Francisc Munteanu, Cerul n-are gratii is, to some extent, a parable about socialist art in general, and, by extension, about socialist cinema; its implicit message is that the progression towards politically infused, accessible art is inevitable. It tells the story of a naturally gifted young painter, Mihai, who is discovered in the late 1930s by a country priest and employed to paint religious icons for the local church. Accidentally, works by the young painter (played by Vasile Ichim) catch the eye of a somewhat exalted and affluent art critic. Convinced that he's discovered an artist with considerable potential, which would benefit from a formal education in arts, the art critic manages to convince Mihai to move to Bucharest and enroll in the Fine Arts Academy. Struggling to survive and in search of an artistic model to emulate, Mihai is at first drawn to the cultural 
milieu his accidental patron frequents; this is how he gets to meet an older, accomplished painter, named Marcian (played by Tudorel Popa). Marcian, as a character and as a caricature of the modernist artist typical for the pre-socialist, interwar period, embodies all the negative traits of modernism, as it is habitually defined and criticized in the 1950s and, to some extent, early 1960s, in socialist Romania: he is a proponent of an elitist, cosmopolite vision of art, he is a practitioner of aestheticism and, although he does not express any firm political opinions, he is complicit - as the film does not fail to imply - in the rise of the fascist Romanian political movement known as the Iron Guard. The film, which sketches the divergent careers of the two painters, conceives the character Mihai as the polar opposite of Marcian; while the younger painter also claims initially to be apolitical, he soon discovers his affinities with the communist movement, as he makes acquaintances with another fellow student and a professor at the Academy, both members of the Communist Party, and learns how useful his art can be at galvanizing those which seem to be the ideal audience for his paintings - that is, the large masses of oppressed workers. While he never gets to exhibit his works in a proper gallery, his improvised exhibition, displayed en plain air, on the walls of a dilapidated building, and his topical drawings, reproduced in the left-leaning press, turn him almost overnight into a symbolic figure for a new kind of (anti-modernist) art - rejected by the art establishment, but in tune with the social and political evolutions of the moment.

The narrative of the film, which largely incorporates the romantic myth of the artiste maudit, with a socialist twist (although ultimately ignored by art institutions, Mihai is told by one of the workers that he is, nevertheless, "their artist"), deceptively suggests that socialist art evolves in natural opposition to the precepts of modernist art and that it has no connections to the interwar modernist tradition. In fact, as Irina Cărăbaș has persuasively argued ${ }^{1}$, from its very beginnings, the communist regime tried to co-opt for the new, postwar Fine Arts Institute "Nicolae Grigorescu" some of the most remarkable painters of the interwar era and, following Khrushcev's cultural Thaw, seemed able to tolerate deviations from the new style of art promoted by cultural officials which were akin to the dominant styles developed by Romanian painters in the interwar era. Thus, the opposition between Western modernist influences and spontaneously-generated socialist art, as embodied by Marcian and Mihai, is at best theoretical and at worst misleading. In 1963, when Munteanu's film was released, this opposition still mirrored the official pronouncements printed on the first pages in the Romanian cultural press; these pronouncements equally characterized Western modernist art as elitist, incomprehensible, apolitical or reactionary, and decadent. In Cerul n-are gratii, Marcian's latest painting, deemed by the artist a visual, non-figurative interpretation of Beethoven's Fifth Symphony, functions as an ironical example of such art; while Marcian considers it to be self-explanatory, one of the characters in the film remarks upon seeing it: "such a curious thing, art - you watch and you don't understand a thing." However, such clearly-drawn lines between Western modernism and socialist art were less and less invoked by that time 
in the interventions published in cultural press by Romanian artists and cultural officials; "modernism," as a concept, was usually avoided, but the idea of a modern socialist art slowly infuses those debates which try to define the state of contemporary Romanian arts.

Cerul $n$-are gratii was the first Romanian film to address issues such as the role of art and its political implications; ironically, by the time of its release, its statement was out of synch with the prevalent mood of the Romanian artistic milieus. In fact, in Romania the early 1960s were characterized by a subtle, but quite significant change of vocabulary: in matters of cinema, for instance, concepts endlessly debated in the cultural press, such as "contemporary style" or even "realism," could hardly disguise the fact that the actual issue at stake was the incremental incorporation of Western, modernist themes and techniques into Romanian films. ${ }^{2}$ The pleas for films with a more modern look were formulated, to be sure, as pleas for a cinema that would more accurately reflect contemporary socialist reality. However, socialist modernism slowly evolved into a style that closely resembled his Western counterpart - the other, much maligned modernism. Many films made starting with the mid 1960s embodied this contradiction - to be sure, they were socialist in terms of content, they reflected the many facets of socialist modernity, but they were also modernist in terms of their form and their latent implications, and as such they embodied issues and anxieties which contradicted and subverted the tenets of socialist art. Some of the films which were heavily criticized and even withdrawn from cinemas in the late 1960s, such as Lucian
Bratu's Un film cu o fată fermecătoarel $A$ Charming Girl (1967), Mircea Săucan's Meandrel Meanders (1967), Savel Stiopul's Ultima noapte a copilărieil The Last Night of Childhood (1968) or Lucian Pintilie's Reconstituireal Reenactment (1970), were examples of a clash between these two versions of modernism - or, rather, of a clash between the expectations of those officials in charge of the Romanian film industry concerning how the socialist modernizing project should be reflected in cinema and the eagerness of many film directors to emulate Western modern cinema. In this respect, Munteanu's Cerul n-are gratii can be seen as a late affirmation of socialist realist positions concerning art, a final statement of a style which slowly disintegrates during the 1960s; before long, the two competing versions of modernism would lead to a divide which would characterize Romanian cinema until the fall of communism.

\section{The Look of Socialist Modernity}

ne of the first consequences of Khrushchev's cultural Thaw, as far as cinema is concerned, was a shift in emphasis - from films which could be described as mythological origin stories of the new socialist societies to films which were meant to address the specific issues of contemporary socialist societies. Thus, the film on contemporary topics quickly became in the late 1950s, in the Soviet Union, but also in the Eastern socialist states, a major concern for film officials. Script writers and directors were encouraged to tackle contemporary subjects, but they were also expected to follow tacit rules implicit in the tenets of socialist art. One such tacit rule was the emphasis on progress: films were expected 
to underline the general evolution of the socialist society, while equally conveying the inevitable transition towards socialist values (solidarity, moderation, a strong work ethic, and so on). Traits such as these are nowadays considered by some film historians as symptomatic for the ideological involvement of the socialist state in the production of films. Nevertheless, it can be equally argued that those playwrights and novelists who accepted in the late 1950s and early 1960s to adapt their works to film (in the language of the day, they were the authors of "literary scripts," soon to be redacted and transformed by the directors themselves into "directorial scripts") adjusted their creative vision to the new requirements imposed by the party in power. Whatever their motives could have been from sheer opportunism to a sincere belief in the cause of socialism -, the resulting scripts are to some extent an approximation of a utopian vision of the socialist society, as interpreted back in the day by an educated elite. From 1956 to 1958, when the effects of the cultural Thaw were felt in Romanian cinema, dissenting voices were even able to complain about the limits imposed by film officials on the creative freedom of script writers. From 1958 onward, for about a half a decade, due to an abrupt reversal of the more relaxed cultural policies of the mid- to late 1950s, very few films managed to problematize the optimist vision of the socialist society that film officials and state apparatchiks formally endorsed. The films released in both these periods are, nevertheless, quite similar in their approach to contemporary life. They usually present, in a positive manner, the advancements of the Romanian industry; they integrate into their narratives the large-scale projects of urbanization; they have as characters young men and women who find a purpose in their work and learn, through their experiences, the importance of socialist values; and they emphasize the importance of a state-sponsored culture aimed at reshaping the habits of cultural consumption characteristic for the inter-war era.

Such a film is, for instance, Marius Teodorescu's Mândriel Pride, released in 1961 and based on a script co-written by Teodorescu himself and the writer Alecu Ivan Ghilia. The plot of the film revolves around a conflict between a young, ambitious engineer, Andrei (played by Victor Rebengiuc) and his superior and soon-tobe father-in-law, Liviu (played by Emanoil Petruț). After a brief stage in Moscow, Andrei returns to the steel plant he used to work in and has to come to grips with the authoritarian style in which Liviu is managing the production. Andrei himself has new ideas concerning the increase in steel production - as many other films produced around that time in socialist Romania, the clash of ideas in Teodorescu's film mainly relates to the right means of increasing industrial productivity. Beyond such topical concerns, the film nevertheless manages to mirror the many ways in which the characters get to enjoy, in their spare time, the comforts of modern life - for instance, in one sequence, Andrei goes yachting with a friend, while in another he picks up his fiancée (played by Ilinca Tomoroveanu) from her tennis practice. Like in other films on contemporary topics, there is an equal emphasis in Mândrie on the intricacies of the socialist work ethic (in this respect, the character Liviu is depicted, in a critical manner, as the archetypal socialist manager 
which, out of vanity, tries to exceed production quotas, while virtually ignoring any dissenting opinion on the matter) and on leisure. The contradiction between these two different aspects of modern life - work and leisure - is never addressed; somehow, the characters most obsessed with industrial innovation and productivity seem to find a natural balance between their work (which seems to invade in large measure their private life) and their spare time. In this regard, socialist cinema (and socialist art in general) seems to be infused with those puritan, bourgeois ideas concerning work - as Zygmunt Bauman notes in his 1976 book, Socialism: The Active Utopia that the Marxist critique of the capitalist system had condemned in the first place. Teodorescu's Mândrie, alongside other films released in the late 1950s and early 1960s, depicts a society which closely resembles a utopian community built around values such as work, voluntary involvement in the modernization project and moderate consumption. Leisure, as it is depicted onscreen, seems to be the implicit reward and the definitive mark that signals the success of the socialist modernization project.

Utopian as it may be, this vision of a well-adjusted society, which equally values challenging work and leisure, this sense of enthusiasm for the socialist modernization project may have been genuinely felt at the beginning of the 1960s. Contrary to the wide-spread narrative which states that in socialist countries the parties in power managed to hold on to that power mainly by repressive means, in certain periods these parties tried to legitimize themselves through their relative openness to Western products (including cultural products) and through their capacity to provide a decent standard of living for the majority of the population. Such a period is, for Romania, the 1960 s - frequently remembered, in accounts gathered by historians, with great nostalgia by those who lived during this decade. ${ }^{3}$ It was a decade in which Western films became relatively available to Romanian audiences - due to a number of treaties concerning cultural exchanges, for instance, with France and Italy in the late 1950s and with the United States in 1963 - and Western goods were available in Romanian stores. This prosperous decade left its mark on most films made in the 1960s. In them, one can notice the emphasis on leisure, the vibrant night life, the partial synchronization with modes of consumption typical for Western Europe at that time. In one of these films, Malvina Urșianu's Gioconda fără surâs/ Mona Lisa without That Smile (1968), in itself a good example for the way in which Romanian films of the late 1960s incorporate modernist anxieties and the formal sophistication of Western modernist cinema, the protagonists, who have come of age during the first decade of communist rule, appear to be overwhelmed by the new demands of modern life. They appear to regard with general unease the stupendous energy of the new generations of youngsters and they only partially identify with the new, modern lifestyles. Such a depiction of a "lost generation," unable to connect to the vibrant mood of the decade, is nevertheless atypical for Romanian cinema at that time. Rather, many films on contemporary topics released during the 1960s insert into their narratives scenes which seem to celebrate socialist modernity and which give the sense of an evolution towards an ideal-type, atemporal society, infused by socialist values, but 
equally influenced (if one pays attention, for instance, to the soundtrack of these films, replete with Western pop and rock 'n' roll music) by Western modernity. It is precisely this amalgamation of styles and attitudes - it itself, a direct consequence of the relative openness of the regime towards Western cultural products - which will become problematic in Romanian films towards the end of the 1960s.

\section{Towards Cinematic Modernism}

I $n$ terms of aesthetics, the most important evolution in Romanian cinema in the late 1950s and early 1960s is the slow dismantlement of the socialist realist doctrine. In those years equally characterized by chaotic "thaw" and "freeze" signals, there was no comprehensive critique of socialist realism in cinema. Instead, the main tenets of the socialist realist method were slowly and cautiously abandoned, one by one. For instance, in the first "thaw" period, starting with 1956, one of the first features of socialist realism to be criticized was the so-called theory of the "typical", which stated that characters (in literature, but also in cinema) should be representative (in their actions and personality traits) for the social class they belonged to. As a result of this critique, Romanian films began to feature more complex characters, who evaded the simplistic separation, preeminent in socialist realist art, between positive and negative heroes. Such a character is, for instance, the rancorous party official played by Emanoil Petruț in Gheorghe Turcu's $O$ mică intâmplare!/ A Little Story (1957); although animated by a sincere dedication for the aims of socialism, he lets himself get carried away by his antipathy for the protagonist (played by Marcel Anghelescu) and ends up persecuting him and isolating from the community a potential sympathizer of the socialist cause. (As stated earlier, Petrut would later play a similar role, that of a fervent, but misguided believer in the socialist cause, in Marius Teodorescu's Mândrie.) Such a discreet, but important reevaluation of the content of socialist realism cinema was soon accompanied by a plea for a diversity of styles. Although socialist realist art was, in theory, adverse to formal experimentation and any perceived deviation from a straightforward, accessible style of storytelling was usually sanctioned with the label of "formalism," by the early to mid 1960s Romanian cultural periodical such as Contemporanul were translating from the main Soviet cultural journal devoted to cinema, Iskusstvo Kino, interventions which declared socialist realism to be a somewhat flexible doctrine, or published interviews with renowned Soviet directors who maintained that socialist cinema was entering a new stage, characterized, among others, by formal innovation. For instance, in an interview published in 1962, Lev Kulidzhanov (famed co-director of one of the classic films made during the early cultural Thaw, Dom, v kotorom ya zhivul The House I Live In, released in 1957) argued that the new Soviet cinema was characterized by an "expansion of stylistic tendencies," while concluding that "socialist realism is not a dogma." Such claims from some of the most important voices in Soviet cinema - arguably, during the previous decade, but also in the first year of the 1960s, the dominant model for Romanian cinema - signaled that a revision of the socialist realist doctrine was 
finally possible. In this respect, some of the interventions published by those involved in the Romanian film industry at that time seem to continue the debates initiated in the brief liberalization period of the late 1950s; for instance, in an article concerning the film on contemporary topics, published in 1965, the writer Petre Sălcudeanu (script writer for such a film, Partea ta de vinăl Your Share of Blame, released in 1963) argued that Romanian films did not have to necessarily rely on clear distinctions between negative and positive characters, nor did they have to stick, for the sake of didacticism, to their quasi-mandatory happy endings ${ }^{5}$. Following such apparently minor revisions, towards the mid 1960s, besides a couple of somewhat vague statements, which insisted that Romanian cinema should be socialist in content and that it should critically reflect contemporary socialist reality, not many of the original intentions of the socialist realist doctrine were to be found in the debates and interventions published in the Romanian cultural press.

The transition towards films which incorporated stylistic devices and themes characteristic for Western modernist cinema was, nevertheless, slow. It required a complete reversal of all the assumptions about socialist art which defined socialist realism; if cinema made in the socialist realist vein had to reflect in its content class consciousness, had to avoid unnecessary experimentation with form and was supposed to be accessible to virtually every viewer, modernist cinema was characterized by subjectivity, reflexivity and abstraction. ${ }^{6}$ In this respect, those Romanian film critics, directors and film officials who championed the emulation of Western modernist cinema never claimed that this transition was to affect socialist cinema as a whole; instead, they theorized art cinema as a distinct mode of film practice and they presented art films as alternative cultural products, to be consumed by an educated audience which was keen on challenging, sophisticated art. Auteur cinema, seen as the opposite of mainstream cinema, was thus championed as a necessary step in the evolution of socialist cinema - a phenomenon which largely mirrors similar developments in the Soviet Union, where, due to the recognition gained at Western film festivals by several Soviet films in the late 1950s and early 1960s, some directors, such as Mikhail Kalatozov, Mikhail Romm and Andrei Tarkovsky, were equally hailed as auteurs. ${ }^{7}$ Initially, those same Soviet directors were seen as models for Romanian modernist cinema; this was a convenient strategy, since it implied that the same evolution towards a more personal and sophisticated kind of cinema was characteristic for the Soviet film industry, but it was also a reflection of the scarcity of Western modernist models available to Romanian filmmakers. Indeed, due to the cultural isolation of the 1950s, films by directors which will be frequently quoted as models for Romanian modernist cinema, such as Ingmar Bergman or Luis Buñuel, were first screened in Romania only in 1963, while many other modernist Western films, due to the deficient film distribution, were usually shown in Romanian cinemas with a delay of two or three years. In part, this delayed reception of Western modernist cinema explains the late emergence of Romanian cinematic modernism. While the mid- to late 1960s, with their more relaxed cultural policies, certainly are a favorable 
moment for the transition towards modernism, unlike the first years of the decade, the release of many modernist Romanian films only in the late 1960s, alongside their indebtedness in terms of style to just a couple of Western directors, such as Alain Resnais or Michelangelo Antonioni, has a lot to do with this delayed appropriation of Western modernist cinema.

In theory, modernist traits and an emphasis on socialist values could coexist in the same film - or, at least, that is what many Romanian directors seem to have thought when making films which were breaking away from the tenets of socialist realism. One of the first such films, $\mathrm{Via}^{-}$ ta nu iartăl The Mist is Lifting, released in 1959 and co-directed by Manole Marcus and Iulian Mihu, can barely be defined nowadays as a modernist work; still, with its narrative recounted in long flashbacks, its expressionistic sound effects (a definitive mark for most later Romanian modernist films) and its spectacular opening shots, it marked a definitive departure from the films made in the socialist realist vein in the early 1950s. Nevertheless, it was a film with an anti-war message, emphasizing the communist opposition to armed struggle during World War I, was adapted from some of the writings of the socialist writer Alexandru Sahia, and, as such, even if its release was delayed, it was still regarded by film critics and film officials at that time as an interesting experiment with form. Less well received was Mircea Săucan's Țărmul n-are sfârșitl The Endless Shore - finished in 1962, but banned by the authorities and screened publicly only after 1989. Due to its almost plotless narrative, its minimal cast (mainly a love story with only two characters, it can be described as a playful version of the 1958 Polish modernist drama The Last Day of Summer, directed by Tadeusz Konwicki) and its unusual filming angles, Săucan's film was accused of "formalism" - although the decision to ban the film might have had a lot to do with the fact that the director had been initially commissioned to make a film on a different topic. Like Viața nu iartă, Tărmul n-are sfârșit wasn't subversive in its content; more likely, it was made at a time when the shift towards a more modern style, towards formal experimentation, was still cautiously suggested by film directors and film critics. Indeed, in a matter of years, films with a more modern look, such as Virgil Calotescu's Camera albăl The White Room (1965), Lucian Pintilie's Duminică la ora 6/ Sunday at Six (1966) and Andrei Blaier's Diminețile unui băiat cumintel The Mornings of a Sensible Lad (1967), were released, and none of them were officially criticized for their style or for their approach to their subjects. In truth, even if their style was more akin to the style of Western modernist films, they relied on some of the favorite themes of socialist mythology and they largely embodied the values of the socialist modernization project. For instance, Blaier's Diminețile unui băiat cuminte featured a fractured narrative, relied on a shifting, imprecise chronology and the distorted sound effects characteristic for modern cinema; it also translated onscreen the anxieties of a new type of character, the young misfit - misunderstood by his parents, enraged by the subtle class differences which were manifesting themselves in the socialist society. Nevertheless, the protagonist's character arc was typical for socialist cinema - from a skeptic, he was turning, 
by the end of the film, into a believer in the value of hard work, solidarity and moderation. The anxieties of socialist modernity, which were beginning to permeate Romanian cinema, found an effortless solution in the narrative of these films.

The few modernist films which were heavily criticized or withdrawn from cinemas in the late 1960s and early 1970s, later to become cause célèbres of the Romanian cinema, were not substantially different in form or content from the films already mentioned. It has been frequently implied that films such as Meandre, Un film cu ofată fermecătoare or Reconstituirea were to some extent subversive in their content or embodied anti-authoritarian stances which the apparatchiks of the regime found hard to tolerate. In fact, the almost constant reaction that these films elicited was a rejection of the personal values the protagonists of these films personified. In some cases, style was also an issue; for instance, Săucan's Meandre, quickly hailed by film critics as representative for a new, modern kind of cinematic language, was nevertheless a difficult, abstract film, and although it was quite unproblematic in terms of content, it was withdrawn from distribution after it had been screened for only a couple of weeks. Still, the main issue with these films was their take on socialist modernity - less critical than one might expect from the excessive reactions, but nevertheless ambiguous. The usually young protagonists were socialist versions of the kind of misfits which were so characteristic for Western arthouse films. Their behavior was erratic, eccentric, and they exhibited a tragic playfulness which seemed out of tune with the optimist tone of socialist cinema. Unlike the protagonist in Diminețile unui băiat cuminte, they seemed incapable to find role models or meaning in their proximity. Pintilie's Reconstituirea, for instance, was criticized exactly for its portrayal of its young protagonists; deemed unrepresentative for their actual, contemporary peers, these characters were nevertheless acting along the lines of a new, Western youth culture that valued irony, nonconformity and individual expression, rather than tradition, social cohesion and moderation. Such films were not critical of the socialist modernizing project as a whole; rather, as their Western, modern equivalents, they emphasized the contradictions of modernity, the mismatch between the desire for individual expression and the constraints of social cohesion. To some extent, they signaled a crisis of the antithetical values which characterized modernity, both in its Western and Eastern versions. It is a matter of debate to what degree such self-critical appraisals were more favorably received by Western elites than by Eastern, socialist ones. Nevertheless, the harsh reactions elicited in the socialist sphere by films which were hardly conceived as political statements are indicative of the limits of socialist modernity. While in theory cultural products, including films, were supposed to reflect in a critical manner the many aspects of socialist modernity, they were less able to put into question the values which underlined such a project. As an undesired effect, due to the harsh condemnation of some modernist films which tried to question these values, Romanian film critics (and, retrospectively, film historians) got in the habit of equating those films which reflected in a positive way the socialist modernizing project with state-sponsored propaganda. To a certain degree, this assumption 
obscures the main intention inherent in the transition towards Romanian cinematic modernism, that of synchronizing two distinct, but theoretically compatible modes of filmmaking.
This work was supported by a grant of the Romanian Ministry of Research and Innovation, CCCDI-UEFISCDI, project number PN-III-P1-1.2-PCCDI-2017-0326/49 PCCDI, within PNCDI III.

\section{Notes}

1. Irina Cărăbaș, Realismul socialist cu fața spre trecut. Instituții și artiști în România: 1944-1953, ClujNapoca, Ideea Design \& Print, 2017.

2. See, for instance, my essay on this matter, "The Slow Break from Socialist Realism: Romanian Cinema in the Late '50s and Early '60s," in Irina Trocan (ed.), Romanian Cinema Inside Out - Insights on Film Culture, Industry and Politics (1912-2019), Romanian Cultural Institute Publishing House, forthcoming.

3. See, for instance, Jill Massino, "From Black Caviar to Blackouts: Gender, Consumption, and Lifestyle in Ceaușescu's Romania”, in Paulina Bren, Mary Neuburger (eds.), Communism Unwrapped. Consumption in Cold War Eastern Europe, New York, Oxford University Press, 2012, pp. 226-249.

4. "Cu Kulidjanov despre actualitate și film" [Lev Kulidzhanov on Contemporaneousness and Cinema], Contemporanul, no. 6 (800), 1962, p. 5.

5. Petre Sălcudeanu, "Filmul românesc de actualitate" [The Romanian Film on Contemporary Topics], Contemporanul, no. 24 (974), 1965, p. 5.

6. András Bálint Kovács, Screening Modernism: European Art Cinema, 1950-1980, Chicago: University of Chicago Press, 2007, p. 204.

7. Eugénie Zvonkine, "Auteur Cinema during the Thaw and Stagnation," in Birgit Beumers (ed.), A Companion to Russian Cinema, Malden, Willey-Blackwell, 2016, pp. 178-201. 